\title{
Pendekatan Metode Double Advancement Flap untuk Operasi Tumor Kulit pada Anjing
}

\author{
Leni Maylina $^{1 *}$, Citra Ayu Lestari ${ }^{2}$, Elma Nefia ${ }^{2}$, Siti Sarah Ulia $^{3}$, Christia Dilla $^{3}$, Siti Komariah $^{3}$ \\ ${ }^{1}$ Departemen Klinik, Reproduksi dan Patologi, Fakultas Kedokteran Hewan, Institut Pertanian Bogor \\ ${ }^{2}$ Program Pendidikan Profesi Dokter Hewan, Fakultas Kedokteran Hewan, Institut Pertanian Bogor \\ ${ }^{3}$ Animal Clinic Jakarta (ACJ), Jakarta Selatan
}

ABSTRAK: Anjing King Charles Spaniel (KCS) dan Golden Retriever (GR) berumur dua tahun memiliki jenis kelamin jantan datang ke Animal Clinic Jakarta (ACJ) pada tanggal 8 November 2016 dengan gejala klinis adanya pertumbuhan massa kenyalyang menempel pada kulit di bagian thoraks kanan (KCS) dan di kaki kiri depan, ventral thoraks dan pada daerah scapula kanan (GR). Hasil pemeriksaan darah lengkap dan kimia darah menunjukkan kedua anjing boleh dilakukan anaesthesia untuk terapi pengangkatan tumor. Terapi yang dilakukan adalah operasi pengangkatan tumor dengan luka operasi ditutup menggunakan metode penjahitan double advancement flap. Terapi injeksi yang diberikan pada kedua anjing setelah operasi yaitu pemberian antibiotik Ceftriaxone ${ }^{\circledR}$. Terapi oral untuk rawat jalan yang diberikan adalah Cefadroxil ${ }^{\circledR}$ dan $_{\text {Metacam }}{ }^{\circledR}$ syrup. Tambahan terapi oral untuk anjing KCS adalah Metronidazole ${ }^{\circledR}$ dan Tramadol ${ }^{\circledR}$. Operasi berhasil dengan baik dan kedua anjing diperbolehkan pulang dengan rawat jalan.

Kata kunci:

anjing, double advancement flap Golden Retriever, King Charles Spaniel, tumor kulit

\section{PENDAHULUAN}

Tumor kulit merupakan pertumbuhan tidak terkontrol yang menyerang kulit atau jaringan lunak di bawah kulit dan dapat bersifat jinak atau ganas (Thompson 2012). Penanganan tumor kulit adalah dengan cara pengangkatan tumor melalui operasi. Masalah yang sering muncul adalah besarnya jaringan tumor mengharuskan membuang kulit dengan ukuran besar sehingga membutuhkan metode penjahitan luka yang baik agar persembuhan luka dapat terjadi dengan cepat. Salah satu metode penutupan luka yang digunakan adalah metode double advancement flap (DAF). Advancement flap berfungsi untuk menutup daerah luka dengan kulit yang berdekatan dengan luka beserta pasokan vaskularisasi darahnya sehingga mencegah terjadinya nekrosa jaringan. Suplai darah untuk flap berasal dari plexus subdermal kulit. Advancement flap H-plasty seperti yang disebutkan oleh Koch (2011), dilakukan dengan dua advancement flap dari setiap sisi untuk menutup area perlukaan atau disebut DAF. Dua kasus yang ditangani dalam studi kasus ini didiagnosa tumor kulit dan dilakukan terapi operasi metode penjahitan DAF.

\section{- TEMUAN KLINIS}

Anjing King Charles Spaniel (KCS) dan Golden Retriever (GR) berumur 2 tahun dengan jenis kelamin jantan datang ke Animal Clinic Jakarta pada tanggal 8 November 2016 dengan pertumbuhan massa kenyal pada kulit di bagian thoraks kanan (KCS) serta di kaki kiri depan, ventral thoraks, dan daerah scapula kanan (GR). Hasil pemeriksaan fisik anjing KCS didapatkan bobot badan $12.8 \mathrm{~kg}$, suhu tubuh $37.8^{\circ} \mathrm{C}$, dan detak jantung $112 \mathrm{bpm}$, sedangkan pada anjing GR didapatkan bobot badan $31.2 \mathrm{~kg}$, suhu tubuh 38.5 ${ }^{\circ} \mathrm{C}$, dan detak jantung $120 \mathrm{bpm}$.

\section{- HASIL DAN PEMBAHASAN}

Pemeriksaan penunjang yang dilakukan adalah pemeriksaan darah lengkap dengan hasil parameter eritrosit, leukosit dan trombosit normal. Hasil pemeriksaan kimia darah untuk fungsi hati dan fungsi ginjal masih dalam batas nilai normal disertai dengan hiperproteinemia serta nilai bilirubin dan kreatinin normal tinggi. Hasil pemeriksaan darah lengkap dan kimia darah menunjukkan kedua anjing boleh dilakukan anaesthesia untuk terapi pengangkatan tumor.

Terapi yang dilakukan adalah operasi pengangkatan tumor dengan luka operasi ditutup menggunakan metode penjahitan DAF. Tahap persiapan yang dilakukan yaitu anjing diinjeksi premedikasi Atropin Sulfat ${ }^{\circledR} 0.022 \mathrm{mg} / \mathrm{kg}$ berat badan secara subkutan. Kemudian anjing diberikan sedativa

\footnotetext{
Diterima : 21 Juli 2017

Direvisi : 8 Agustus 2017

Disetujui : 11 Agustus 2017
} 
yaitu Valium ${ }^{\circledR}$ dengan dosis $0.1 \mathrm{mg} / \mathrm{kg}$ berat badan secara intravena. Setelah itu untuk mencegah infeksi sekunder, anjing di injeksikan antibiotik Ceftriaxone ${ }^{\circledR}$ dengan dosis 15 $\mathrm{mg} / \mathrm{kg}$ BB secara intravena. Setelah 10 sampai 15 menit kemudian anjing diberikan Propofol ${ }^{\circledR}$ dengan dosis 0.5 $\mathrm{mg} / \mathrm{kg}$ berat badan secara intravena. Sekitar 5-10 menit setelah diinduksi dengan Propofol $^{\circledR}$, diberikan $1-4 \%$ Isofluran $^{\circledR}$ dalam oksigen murni secara inhalasi.

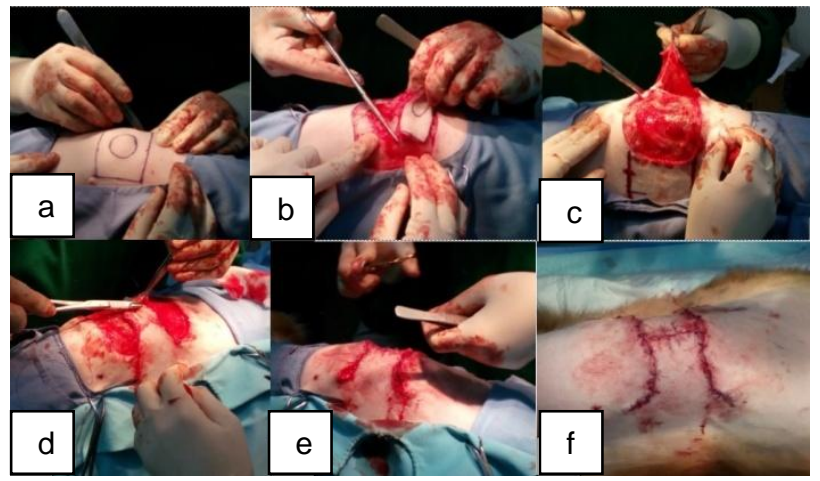

Gambar 1 Operasi pengangkatan tumor kulit anjing King Charles Spaniel dengan penjahitan luka metode DAF (a) peyayatan kulit; (b) preparir tumor; (c) pemisahan kulit dengan subkutan; (d) penjahitan kulit bagian tengah; (e) penjahitan kulit bagian tepi; (f) Hasil metode DAF.

Prosedur bedah pada anjing King Charles Spaniel ditampilkan pada Gambar 1, sedangkan Gambar 2 memperlihatkan prosedur bedah pada Anjing Golden Retriever. Penggambaran pola dan batas-batas penyayatan dilakukan sebelum insisi. Penyayatan kulit yang dilakukan cukup luas yaitu disekitar area tumor berupa bidang persegi. Tumor yang terdapat di bawah kulit dipreparir dan diangkat dengan sangat hati-hati. Setelah itu dilakukan metode DAF untuk menutup area perlukaan. Metode DAF pada operasi anjing KCS dan GR dilakukan dengan menggambar pola kulit yang akan digunakan untuk menutup luka (skin donor site). Kemudian bidang sayatan diperluas mengikuti pola pada bagian tengah dan preparir bagian kulit agar terpisah dari bagian subkutan. Setelah itu, kulit dari kedua sisi ditarik dan disatukan dengan cara dijahit. Bagian tepi sayatan dipreparir agar kulit terpisah dari subkutan, ditarik dan disatukan dengan bagian tengah kulit yang telah dijahit sebelumnya. Penjahitan dilakukan dengan menggunakan jarum berpenampak segitiga agar mudah mengiris kulit dan benang nilon 3.0 dengan tipe jahitan matras silang. Luka yang telah dijahit kemudian dibersihkan dengan normal saline dan ditutup menggunakan Lomatuell ${ }^{\circledR}$ dan Hypafix ${ }^{\circledR}$. Bagian luka operasi dilakukan bandage dengan metode tuxedo serta digunakan tubular bandage sebagai perban tekan agar jika terbentuk cairan seroma dapat keluar serta untuk menahan bandage agar tidak mudah lepas.

Terapi injeksi yang diberikan pada kedua anjing setelah operasi yaitu pemberian antibiotik Ceftriaxone ${ }^{\circledR}$ dengan dosis $15-50 \mathrm{mg} / \mathrm{kg}$ berat badan. Pemberian injeksi selanjutnya digantikan dengan obat oral. Terapi oral yang

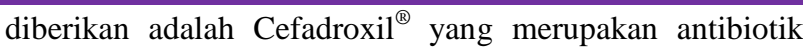
spektrum luas dengan dosis $10-25 \mathrm{mg} / \mathrm{kb}$ berat badan, dan Metacam ${ }^{\circledR}$ syrup dengan dosis $0.1 \mathrm{mg} / \mathrm{kg}$ berat badan sebagai obat anti inflamasi non steroid (Plumb 2005). Tambahan terapi oral Metronidazole ${ }^{\circledR}$ sebagai antimikroba dengan dosis $10-20 \mathrm{mg} / \mathrm{kg}$ berat badan dan Tramadol ${ }^{\circledR}$ sebagai pereda rasa sakit dengan dosis $5-10 \mathrm{mg} / \mathrm{kg}$ berat badan (Plumb 2005) diberikan pada anjing KCS.

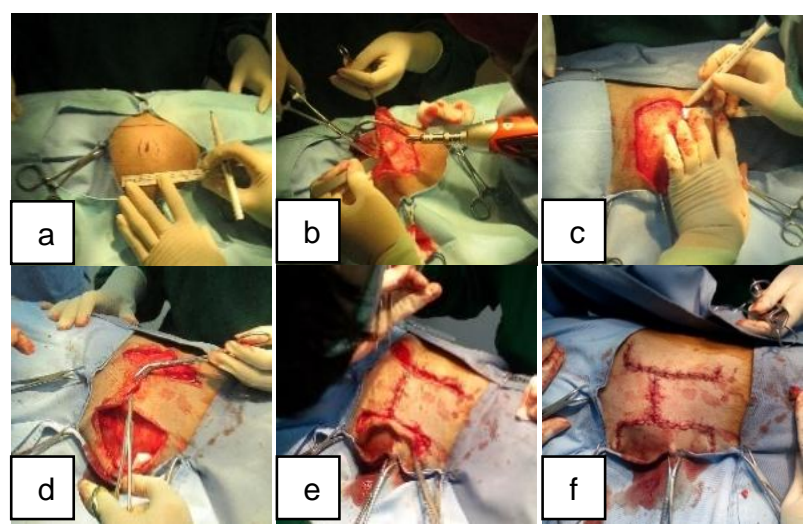

Gambar 2 Operasi pengangkatan tumor kulit anjing Golden Retriever dengan penjahitan luka metode DAF (a) pengukuran area sayatan; (b) preparir tumor; (c) pengukuran skin donor site; (d) penjahitan kulit bagian tengah; (e) penjahitan kulit bagian tepi; (f) Hasil metode DAF.

\section{- SIMPULAN}

Kedua anjing King Charles Spaniel (KCS) dan Golden Retriever (GR) didiagnosa mengalami tumor kulit pada bagian lateral sinistra thoraks (KCS) serta ventral thoraks, kaki kiri depan dan scapula kanan (GR). Tindakan yang dilakukan pada kedua anjing yaitu operasi pengangkatan tumor dengan menggunakan metode penjahitan DAF untuk menutup daerah luka. Operasi berhasil dengan baik dan kedua anjing diperbolehkan pulang dengan rawat jalan.

\section{- INFORMASI PENULIS}

Penulis untuk Korespondensi

lenimaylina@gmail.com

\section{- UCAPAN TERIMA KASIH}

Terima kasih kepada pimpinan dan tim dokter Animal Clinic Jakarta (ACJ) serta Kelompok E Program Pendidikan Profesi Dokter Hewan (PPDH) Angkatan II Tahun 2015-2016 yang melakukan magang kerumahsakitan di ACJ.

\section{- PUSTAKA ACUAN}

Koch D. 2011. Handout Advanced Course in Small Animal Surgery [Internet]. [Diunduh 2017 Maret 28]. Tersedia pada: http://www.dkoch.ch/xp_wysiwyg_media/English_Website/Ha ndout_Advanced_Course_in_Soft_Tissue_Surgery_2011.pdf.

Plumb DC. 2005. Veterinary Drug Handbook Ed-5.Iowa (US): Blackwelll Pub.

Thompson. JJ. 2012. Canine mast cell tumours: characterization of subcutaneustumours and receptor tyrosine kinase profilling [Thesis]. Ontario [CA]: University of Guelph. 